\title{
The use of polymer super absorbent in the adaptation of revitalized grape plants to non- sterile conditions
}

\author{
Ekaterina Lopatkina*, and Anton Rebrov \\ Potapenko All-Russian research institute of Viticulture and Winemaking - branch of the Federal \\ Rostov agricultural research center, prosp. Baklanovcky, 166, Novocherkassk, Rostovskaya obl., \\ 346421, Russian Federation
}

\begin{abstract}
The article discusses the effect of a cross-linked copolymer of potassium and ammonium salts of acrylic acid "Aquasin" on in vitro revitalized grape plants when adapting to non-sterile conditions and growing completion before planting in open ground. The research was carried out on the basis of VNIIViV named after Ya.I. Potapenko on the indigenous Don variety Krasnostop Zolotovsky and the indigenous Crimean variety Kandavasta. The aim of the study was to study the usage effectiveness of super absorbents (hydrogels) for the post vitro stage. As a result, the positive effect of adding the water-retaining agent Aquasin to the substrate on the growth and development of plants was noted. This was especially reflected in such indicators as ripening and the shoots' diameter. In addition, the possibility of preliminary saturation of the super absorbent with immunostimulants or fertilizers is of interest.
\end{abstract}

\section{Introduction}

Polymeric super absorbents are a class of polymeric materials that can absorb and retain large amounts of water and aqueous solutions. They consist of three-dimensional polymer networks that do not dissolve in water but swell significantly in an aqueous medium. Polymeric super absorbents find their application in many spheres of life: industry, environmental protection and, especially in agriculture [1,2]. Agriculture is one of the most important sectors of the national economy. This is due to the ever-increasing demand for food products caused by the growing population. The property of super absorbents to preserve and, if necessary, to release moisture and fertilizers in the soil for plants is the most important for agriculture [3].

Research on the use of super absorbents in agriculture is carried out all over the world $[3,4]$. They are widely used for soil reclamation [5]; it is noted that hydrogels can increase the efficiency of using moisture by plants under stress conditions [6]. The use of polymer super absorbents for growing grain crops on different types of soils was studied: sandy [7], soddy podzolic [8], ordinary chernozems [9]. Super absorbents have also found their application in viticulture. The influence of absorbents was studied when planting vineyards

* Corresponding author: zontanga@rambler.ru 
directly in open ground in order to increase the period of moisture retention at the required depth and distance from the root system of cultivated plants. The super absorbent easily absorbs water, retains (accumulates) it, and, if necessary, gives it to the root system of the plant. Moreover, this process can be repeated almost an unlimited number of times until the complete disintegration of the absorbent substance. Thus, the use of this absorbent can help to increase the number of established seedlings, enhance growth processes, and helps to easily endure adverse environmental conditions (drought, dry winds, frosts, etc.) [10].

The use of super absorbent was studied not only during planting but also directly on fruit-bearing vineyards. In this case, the preparation is applied using an auger into the holes next to the bush. As a result of the research, it was found that the use of hydrogel contributed to an increase in the average weight of grape bunches by $6-13 \%$, which made it possible to obtain 4-12 cwt/ha of additional product relative to the control. In addition, it was noted that improving the water supply of a grape plant due to hydrogel introduction contributed to the efficiency increase of applied nitrogen fertilizers [11].

Polymer super absorbents are also used in the production of planting material in sheltered ground. The regenerative abilities of grape varieties were studied depending on the introduction of various hydrogel concentrations into the substrate under conditions of a glasshouse without heating. It has been established that the optimal dose is the option with the introduction of 0.5 and $1.0 \mathrm{~g}$ of hydrogel per $400 \mathrm{~g}$ of dry soil, since the highest average growth of shoots, the percentage of survival and the yield of standard seedlings was observed. A further increase in the hydrogel concentration in the soil led to a decrease in the survival rate and growth of shoots on vegetating grape seedlings [12].

The use of polymer hydrogels at the adaptation stage to non-sterile conditions of in vitro revitalized grape plants is also of interest [13]. For example, the influence features of AQUASORB $3005 \mathrm{~KB}$ hydrogel on the suitability of substrates were considered (a mixture of peat with perlite in a 5:1 ratio; ion-exchange substrate BIONA-111; a mixture of perlite and BIONA-111 in a ratio of 4:1) for adaptation of pre-rooted in vitro regenerant plants of Marechal Foch grapes to non-sterile conditions. There is a positive trend in the development of shoots and roots, as well as an increase in the survival rate of grape plants when AQUASORB $3005 \mathrm{~KB}$ is added to all types of nutrient substrate [14].

The foregoing determines the relevance of research in this direction.

\section{Materials and methods}

The research was carried out at the All-Russian Research Institute of Viticulture and Winemaking named after Ya.I. Potapenko - branch of FSBSI FRASC. The effect of super absorbent on a revitalized grape plant when adapting to non-sterile conditions ("Aquasin" preparation) was studied. This preparation was provided for the study by the manufacturer. Before application, the preparation was saturated with moisture and dissolved minerals (depending on the experimental option). Then the absorbent was added to the soil nutrient substrate in the gel state $(100 \mathrm{ml}$ per plant). The plants were planted in pots with a capacity of 0.5 liters.

Experimental options corresponded to the following scheme:

1. Control- substrate soil, peat, sand (1:1:1) (without super absorbent);

2. Substrate soil, peat, sand (1:1:1) together with the super absorbent "Aquasin" (1 g/l of water);

3. Substrate soil, peat, sand (1:1:1) together with the super absorbent "Aquasin" (1 g/1 of water), saturated aqueous solution of minerals (macro-micro) $2.5 \mathrm{~g} / \mathrm{l}$;

4. Substrate soil, peat, sand (1:1:1) together with the super absorbent "Aquasin" $(1 \mathrm{~g} / 1$ of water), saturated aqueous solution of minerals (macro-micro) $2.5 \mathrm{~g} / 1$ with the addition of potassium lignohumate $0.01 \mathrm{~g} / 1$. 
Within two weeks after planting in vitro plants for adaptation, the air humidity was maintained close to $100 \%$; over the next two weeks, the air humidity was gradually reduced to the natural air humidity of $65-75 \%$. Plants underwent adaptation and growing completion under 15-hour daylight hours on an APGR (accelerated plant growth racks). Light source - LED lamps with a spectrum and radiation intensity (in the area of the plant leaf apparatus) - 8000-12000 lx, the spectrum composition is close to $2700 \mathrm{~K}$. The air temperature in the room was $22-26 \mathrm{C}^{\circ}$.

The objects of the study were the indigenous Don variety Krasnostop Zolotovsky and the indigenous Crimean variety Kandavasta.

Description of the preparations used in the study:

Super absorbent ("Aquasin" preparation) is represented by granules of spatially crosslinked polymer of acrylic acid based on potassium salt, specially developed modification (Agro) for safe and effective introduction into the soil. According to the manufacturer, the distinctive properties of the modification (Agro) are fast and volumetric moisture absorption, full return of moisture to plants, reduced product consumption, the ability to absorb mineralized moisture. When hydrogel is introduced into the soil, the plant first consumes the available moisture from the soil, then switches to the water stored in the hydrogel. The water absorption rate of the hydrogel directly depends on the composition of water and soil. The hydrogel introduced into the soil improves its properties making the clay soil looser and the sandy soil lumpy.

A complex of macro and microelements (developed by the VNIIViV laboratory of biotechnology) is a specially selected composition of liquid fertilizer, which contains all the main macro and microelements in optimal proportions that promote their absorption and exclude antagonism. Iron is found in a chelated form. Does not contain ballast substances. In total, the complex includes 6 macro and 8 microelements. When compiling it, the needs of a grape plant for each nutritional element were considered (in accordance with the literal data). Concentrations of minerals in the finished working solution (in\% a.c./1): macroelements: N 220.0-4; P 38.7-4; K 300.0-4; Mg 36.6-4; S 63.0-4; Ca 150.0-4; micro elements: Fe 5.0-4; Mn 5.0-4; B 1.0-4; Co 1.0-6; Cu 1.0-6; Zn 2.0-4; Mo 2.0-4; J 4.0-6.

Potassium lignohumate of the AM brand. According to the manufacturer's data, this modification of lignohumates meets the following technical requirements: the total content of humic substances' salts in dry matter not less than $90 \%$. Content of metals, which are cations of humic substances' salts is not less than: potassium - $20 \%$, calcium $-0.5 \%$. Mass fraction of components that are macro- and microelements (\%), not less than: sulfur - 5, silicon - 1.5, magnesium - 0.25, iron - 0.2, copper - 0.04, manganese - 0.02, molybdenum 0.01 , zinc -0.012 , selenium - 0-0.005, boron - 0.15 . Lignohumate completely dissolves even in cool water.

For statistical data processing, the method of confidence intervals was used with an accuracy of $95.0 \%$.

\section{Results and Discussion}

Since the purpose of this study was to study the effectiveness and feasibility of using a super absorbent (hydrogel) for the adaptation stage and growing completion of revitalized grape plants within the framework of the previously developed technology, extreme modes of plant moisture supply were not used (creating an artificial moisture deficit). In this regard, watering was carried out as needed during growing completion, maintaining the substrate moisture content at about $70 \%$. In addition, it was of interest to study the expediency of preliminary hydrogel saturation with mineral and humic substances. Plants' growing completion in the experiment was carried out for 120 days. The data obtained in the experiment are presented in table 1. 
Table 1. Influence of the use of super absorbent Aquasin on the growth and development of revitalized grape plants during adaptation to non-sterile conditions.

\begin{tabular}{|c|c|c|c|c|c|c|}
\hline \multirow[b]{2}{*}{ Option } & \multirow{2}{*}{$\begin{array}{l}\text { Height, } \\
\mathrm{cm}\end{array}$} & \multirow{2}{*}{$\begin{array}{c}\text { Number } \\
\text { of } \\
\text { leaves, } \\
\text { pcs. }\end{array}$} & \multirow{2}{*}{$\begin{array}{c}\text { Number of } \\
\text { internodes, } \\
\text { pcs. }\end{array}$} & \multirow{2}{*}{$\begin{array}{l}\text { Internode } \\
\text { length, } \\
\mathrm{cm}\end{array}$} & \multicolumn{2}{|c|}{ Area of } \\
\hline & & & & & $\begin{array}{c}\text { a leaf, } \\
\mathrm{cm}^{2}\end{array}$ & leaves, $\mathrm{cm}^{2}$ \\
\hline \multicolumn{7}{|c|}{ Krasnostop Zolotovsky 40 days } \\
\hline Control & $\begin{array}{l}16.6 \\
\pm 1.7\end{array}$ & $7.8 \pm 0.9$ & $9.4 \pm 0.9$ & $1.8 \pm 0.3$ & $10.3 \pm 2.9$ & $80.3 \pm 21.0$ \\
\hline Aquasin & $\begin{array}{l}16.8 \\
\pm 2.6\end{array}$ & $8.2 \pm 1.3$ & $9.0 \pm 1.0$ & $1.9 \pm 0.2$ & $10.4 \pm 2.2$ & $85.4 \pm 16.8$ \\
\hline $\begin{array}{l}\text { Aquasin }+ \\
\text { macro-micro }\end{array}$ & $\begin{array}{l}18.2 \\
\pm 1.5\end{array}$ & $8.4 \pm 0.9$ & $10.3 \pm 1.2$ & $1.8 \pm 0.2$ & $11.6 \pm 1.4$ & $97.3 \pm 12.3$ \\
\hline $\begin{array}{l}\text { Aquasin }+ \\
\text { macro-micro }+ \\
\text { lignohumate }\end{array}$ & $\begin{array}{l}17.3 \\
\pm 2.8\end{array}$ & $9.3 \pm 2.3$ & $10.4 \pm 1.3$ & $1.7 \pm 0.2$ & $9.1 \pm 1.8$ & $84.9 \pm 18.8$ \\
\hline \multicolumn{7}{|c|}{ Kandavasta 40 days } \\
\hline Control & $\begin{array}{l}13.4 \\
\pm 2.7\end{array}$ & $7.7 \pm 1.7$ & $9.9 \pm 1.8$ & $1.3 \pm 0.1$ & $5.2 \pm 1.4$ & $40.0 \pm 23.1$ \\
\hline Aquasin & $\begin{array}{r}12.6 \\
\pm 2.7 \\
\end{array}$ & $7.5 \pm 2.1$ & $9.3 \pm 1.9$ & $1.4 \pm 0.3$ & $5.0 \pm 1.6$ & $37.8 \pm 20.6$ \\
\hline $\begin{array}{l}\text { Aquasin }+ \\
\text { macro-micro }\end{array}$ & $\begin{array}{l}10.8 \\
\pm 1.8\end{array}$ & $6.5 \pm 1.5$ & $8.6 \pm 1.5$ & $1.2 \pm 0.3$ & $6.2 \pm 1.7$ & $40.4 \pm 11.1$ \\
\hline $\begin{array}{l}\text { Aquasin }+ \\
\text { macro-micro + } \\
\text { lignohumate }\end{array}$ & $\begin{array}{l}14.4 \\
\pm 1.3\end{array}$ & $6.7 \pm 1.5$ & $9.2 \pm 1.2$ & $1.6 \pm 0.2$ & $7.0 \pm 0.7$ & $46.7 \pm 11.2$ \\
\hline \multicolumn{7}{|c|}{ Krasnostop Zolotovsky 65 days } \\
\hline Control & $\begin{array}{l}24.8 \\
\pm 3.6 \\
\end{array}$ & $7.0 \pm 0.7$ & $11.8 \pm 1.3$ & $2.1 \pm 0.3$ & $25.2 \pm 7.2$ & $\begin{array}{r}176.5 \\
\pm 54.5 \\
\end{array}$ \\
\hline Aquasin & $\begin{array}{l}24.7 \\
\pm 3.8\end{array}$ & $7.3 \pm 0.9$ & $11.6 \pm 1.6$ & $2.1 \pm 0.3$ & $26.3 \pm 4.9$ & $\begin{array}{l}192.0 \\
\pm 29.3\end{array}$ \\
\hline $\begin{array}{l}\text { Aquasin }+ \\
\text { macro-micro }\end{array}$ & $\begin{array}{l}26.8 \\
\pm 2.6 \\
\end{array}$ & $7.6 \pm 0.5$ & $12.6 \pm 1.1$ & $2.1 \pm 0.3$ & $27.9 \pm 2.9$ & $\begin{array}{l}212.9 \\
\pm 15.7 \\
\end{array}$ \\
\hline $\begin{array}{l}\text { Aquasin }+ \\
\text { macro-micro }+ \\
\text { lignohumate }\end{array}$ & $\begin{array}{l}26.7 \\
\pm 3.5\end{array}$ & $7.7 \pm 0.7$ & $12.8 \pm 1.2$ & $2.1 \pm 0.3$ & $26.7 \pm 5.5$ & $\begin{array}{l}205.3 \\
\pm 26.7\end{array}$ \\
\hline \multicolumn{7}{|c|}{ Kandavasta 65 days } \\
\hline Control & $\begin{array}{l}19.4 \\
\pm 2.9 \\
\end{array}$ & $7.0 \pm 1.4$ & $11.3 \pm 1.7$ & $1.7 \pm 0.2$ & $17.7 \pm 3.8$ & $\begin{array}{l}124.1 \\
\pm 33.3 \\
\end{array}$ \\
\hline Aquasin & $\begin{array}{l}17.1 \\
\pm 2.7 \\
\end{array}$ & $6.2 \pm 1.3$ & $10.4 \pm 1.5$ & $1.6 \pm 0.1$ & $14.7 \pm 3.5$ & $91.3 \pm 22.0$ \\
\hline $\begin{array}{l}\text { Aquasin }+ \\
\text { macro-micro }\end{array}$ & $\begin{array}{r}18.0 \\
\pm 3.2 \\
\end{array}$ & $6.0 \pm 0.8$ & $11.0 \pm 1.7$ & $1.6 \pm 0.2$ & $15.2 \pm 5.7$ & $91.0 \pm 29.2$ \\
\hline $\begin{array}{l}\text { Aquasin }+ \\
\text { macro-micro }+ \\
\text { lignohumate }\end{array}$ & $\begin{array}{l}19.9 \\
\pm 2.7\end{array}$ & $5.8 \pm 0.6$ & $11.7 \pm 1.7$ & $1.7 \pm 0.3$ & $15.9 \pm 3.8$ & $92.8 \pm 17.3$ \\
\hline
\end{tabular}

Under the study conditions, the survival rate of varieties Krasnostop Zolotovskiy and Kandavasta did not depend on the experimental option and was about $100 \%$. The following patterns were identified during the first accounting 40 days after plants' planting for adaptation. The varieties evolved and reacted slightly differently to different options. The indicators of plant development were noticeably better in the variety Krasnostop Zolotovsky. This variety was more responsive to the use of fertilizers, responded positively 
to the combined use of hydrogel with fertilizers, as well as to hydrogel with fertilizer and humic acids. At the same time, no effect on development indicators was noted in both varieties during adaptation and growing completion in the options where the hydrogel was used separately without additives. At the same time, it was noted that there was the smallest loss of the lower leaves from drying out during adaptation in both varieties in this option. This can be seen from the difference in the number of leaves and the number of internodes. During adaptation to non-sterile conditions in grape plants post vitro with a decrease in air humidity, drying of leaves formed during growth under sterile conditions is often observed (Fig. 1). This is probably due to the adaptive adjustment of the grape plant, since newly formed leaves are noticeably more productive in photosynthesis and better regulate transpiration. In this case, the new leaves formed are noticeably larger. In this regard, normally there is a temporary decrease in the number of leaves in plants (in this case - by 65 days) but the area of one leaf and the total area of leaves in one plant increase noticeably.
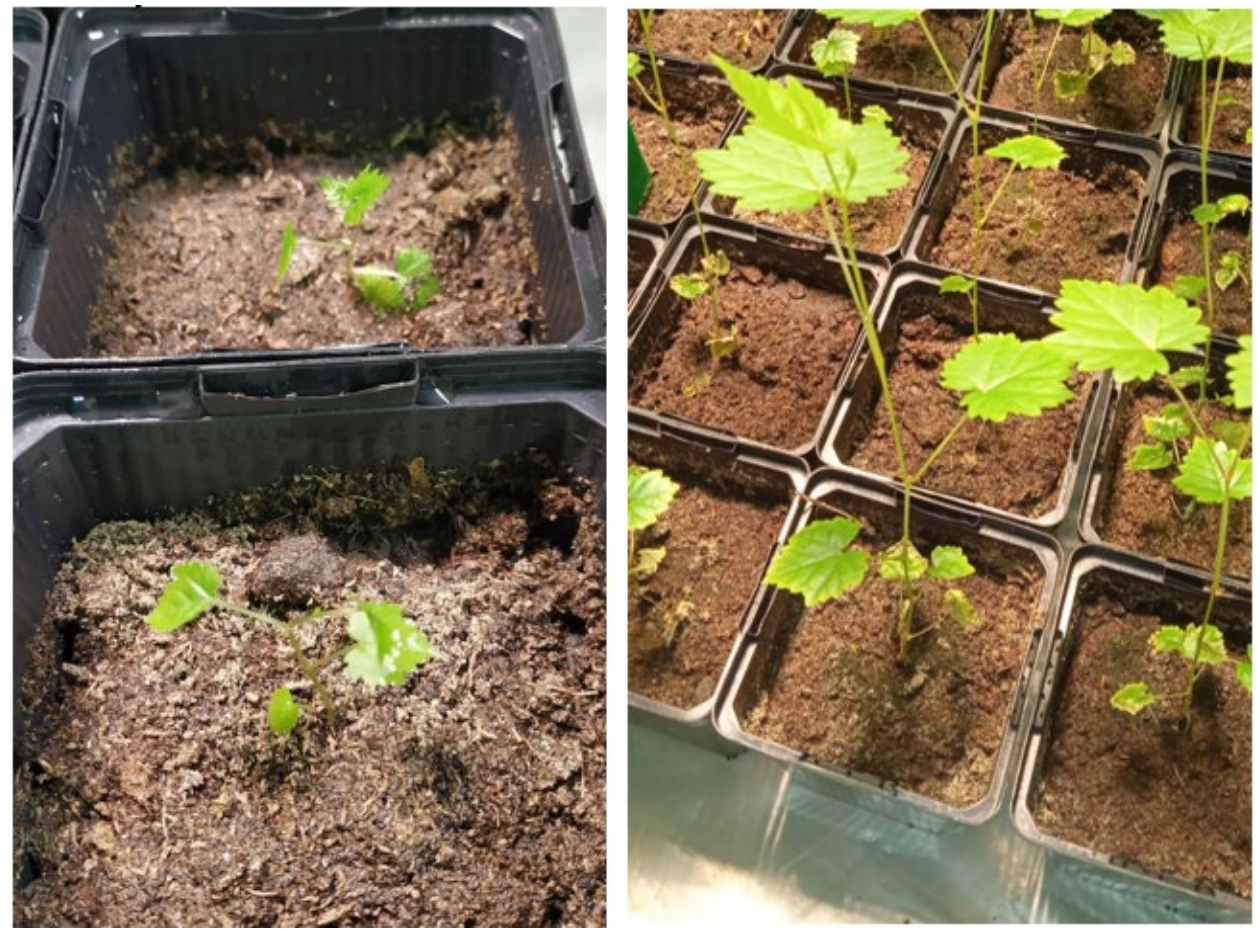

Fig. 1. Condition of plants on the 1 st and on the 65 th day of adaptation.

On the 120th day of the experiment, the development indices between the options were less pronounced, and additional indices of development were of interest - the length of ripening and the shoots' diameter (Fig. 2). For the Krasnostop Zolotovskiy variety, it can be traced that the ripening in the second option is slightly lower than the control, while the third and fourth are superior to the control. The diameter increases from the first to the fourth option from 2.4 to $2.7 \mathrm{~mm}$. 


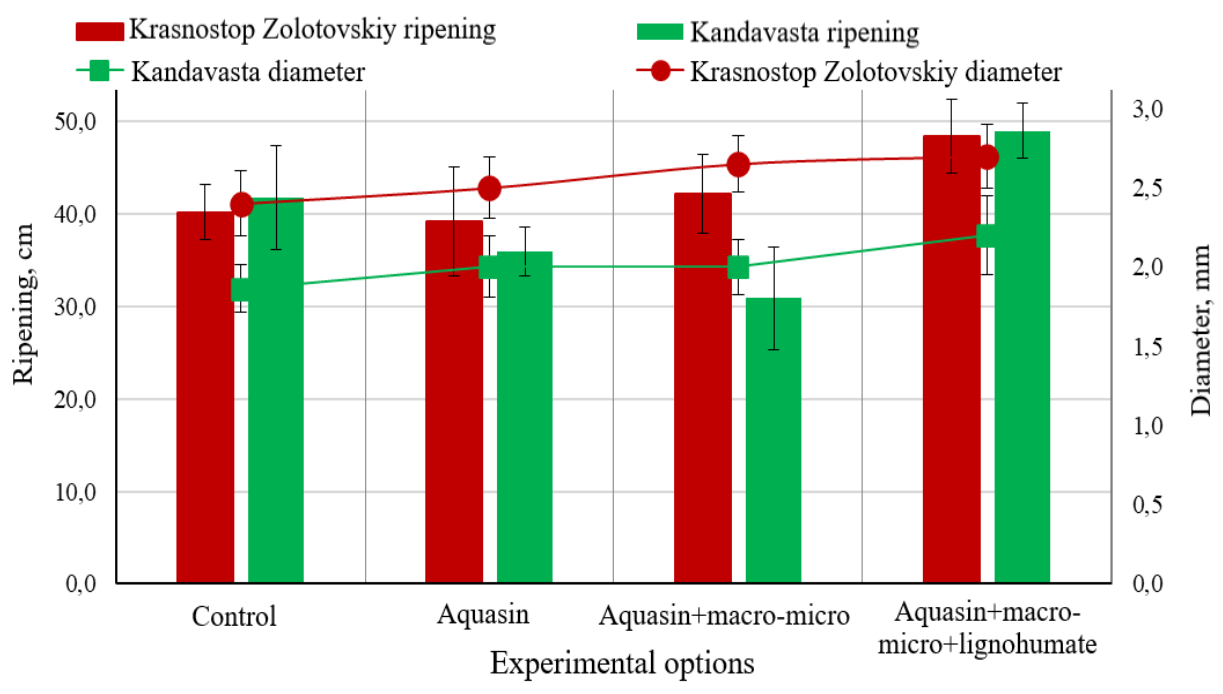

Fig. 2. Ripening indicators and diameter of shoots.

In Kandavasta variety, the control showed the greatest length of the matured shoot exceeding the second and third options yet yielding in this indicator to the fourth; the shoot diameter in the control was lower than in the other options.

\section{Conclusion}

Under the adaptation conditions to non-sterile conditions of test-tube grape microplants, the influence of the water-retaining agent Aquasin added to the substrate on the survival rate of plants was not established. At the same time, it may be of interest to pre-saturate it with fertilizers and immunostimulants such as potassium lignohumate. The addition of super absorbent to the soil substrate has a positive effect on plant growth and development. For Krasnostop Zolotovsky variety, the plant height and leaf area were maximum in the option with the addition of the absorbent saturated with an aqueous solution of mineral substances. The ripening of shoots and their diameter in the Krasnostop Zolotovsky variety were optimal when an absorbent saturated with an aqueous solution of minerals together with potassium lignohumate was added to the substrate. In the Kandavasta variety, the best development indices were normally observed in the control.

With this, the longest ripening length was both in the control and in the option with the addition of the absorbent saturated with an aqueous solution of mineral substances together with potassium lignohumate. In addition, it is necessary to point out the tendency of an increase in the shoots' diameter in both varieties in the options when a hydrogel is added to the substrate.

\section{References}

1. E.M. Ahmed, Journal of Advanced Research, 6, 105-121 (2015) http://dx.doi.org/10.1016/j.jare.2013.07.006

2. M.J. Zohuriaan-Mehr, K. Kabiri Iranian Polymer Journal, 17 (6), 451-477 (2008)

3. S. Behera, P.A. Mahanwar Polymer-Plastics Technology and Materials, 59 (4), 341 356 (2020) https://doi.org/10.1080/25740881.2019.1647239 
4. M.R. Guilherme, A.F. Martins, A.F. Rubira, et al. European Polymer Journal, 72, 365385 (2015) https://doi.org/10.1016/j.eurpolymj.2015.04.017

5. L. Sartore, G. Vox, E. SchettiniJ Journal of Polymers and the Environment, 21, 718725 (2013) https://doi.org/10.1007/s10924-013-0574-2.

6. C. Danielle V.N.Robert W. S.Judith, et al. Journal of Arid Environments, 189 (2021) https://doi.org/10.1016/j.jaridenv.2021.104496

7. T. N. Danilova, Agrophysics, 2 38-43 (2013)

8. T.N. Danilova, L.V. Kozyreva, Plodorodie, 6 (45) 24-25 (2008)

9. E.I. Godunova, V.N. Gundyrin, S.N. Shkabarda, Achievements of science and technology of the AIC 1, 24-27 (2014)

10. M.R. Beibulatov, I. E. Yaroshchuk, Viticulture and winemaking 42, 31-33 (2012)

11. R.G. Rabadanov Fruit and viticulture of the South of Russia, 46 (4), 60-65. (2017) URL: http://journalkubansad.ru/pdf/17/04/06.pdf.

12. A.A. Guguchkina, V.A. Markelov, I. M. Pankin, Success of modern natural science, 6, 71-72 (2002) URL: http://natural-sciences.ru/ru/article/view?id=14933

13. M. Sundyreva, A. Rebrov, A. Mishko, BIO Web of Conferences Bioengineering, 25, 04003, (2020) https://doi.org/10.1051/bioconf/20202504003

14. A.P. Rudnya, Plodovodstvo, 27, 165-172 (2015) 